\title{
PENGEMBANGAN LKS BERDASARKAN HASIL STUDI IDENTIFIKASI JENIS BAMBU DI DESA HARAPAN MAKMUR
}

\author{
Riska Rosalia ${ }^{1 *}$, Ariefa P. Yani ${ }^{1}$, Kasrina $^{1}$ \\ ${ }^{1}$ Program Studi Pendidikan Biologi, Fakultas Keguruan dan Ilmu Pendidikan, Universitas Bengkulu \\ Email : riskabengkulu11@gmail.com
}

\begin{abstract}
Abstrak
Penelitian ini bertujuan untuk mengembangkan LKS berdasarkan jenis-jenis bambu di Desa Harapan Makmur Kabupaten Bengkulu Tengah. Jenis penelitian ini adalah penelitian dan pengembangan dengan metode R\&D. Berdasarkan hasil penelitian yang dilakukan, jenis bambu di Desa Harapan Makmur yang terdiri atas 4 marga bambu dengan 5 jenis bambu yaitu , Bambusa vulgaris var.striata, Bambusa multiplex, Gigantochloa robusta, Schizostachyum lima, dan Dendrocalamus asper. Hasil pengembangan LKS berdasarkan studi identifikasi jenis bambu Desa Harapan Makmur dapat digunakan untuk melatih keterampilan proses dalam proses pembelajaran IPA siswa kelas VII SMPN 1 Pondok Kubang Bengkulu Tengah pada materi klasifikasi tumbuhan berdasarkan ciri morfologi dan kunci determinasinya dengan rerata nilai keterampilan 3,82 berkategori sangat baik dan tuntas.
\end{abstract}

Kata kunci: Bambu, Pengembangan LKS, Keterampilan Proses

\begin{abstract}
The purpose of this research is to develop LKS based on bamboo species in Harapan Makmur Village, Central Bengkulu Regency and to obtain description of the students' process skill based on LKS development from the identification study of bamboo species of Harapan Makmur Village students of grade VII SMPN 1 Pondok Kubang Bengkulu Tengah. This type of research is research and development with R \& D method. Based on the results of research conducted, the type of bamboo in the village of Harapan Makmur consisting of 4 genera of bamboo with 5 types of bamboo namely, Bambusa vulgaris var.striata, Bambusa multiplex, Gigantochloa robusta, Schizostachyum lima, and Dendrocalamus asper. The result of LKS development based on identification study of bamboo species of Harapan Makmur Village can be used to train process skill in science process of VII grade students of SMPN 1 Pondok Kubang Bengkulu Tengah on plant classification material based on morphological characteristic and key of determination with average score of skill 3,82 very good category and complete.
\end{abstract}

Keywords: Bamboo, LKS Development, Process Skills 


\section{PENDAHULUAN}

Indonesia merupakan negara yang sangat kaya dengan sumber daya alam yang potensial, didukung dengan keadaan geografis Indonesia. Adapun salah satu sumber daya alam yang ada di Indonesia adalah tumbuhan bambu. Bambu dapat tumbuh di daerah yang beriklim kering hingga yang beriklim basah, dari dataran rendah hingga ke daerah pegunungan dan biasanya di tempat - tempat terbuka yang daerahnya bebas dari genangan air, pertumbuhannya cepat (3-5 tahun) dapat di panen setiap tahun tanpa merusak rumpun dan memiliki toleransi tinggi terhadap gangguan alam dan kebakaran.

Berdasarkan observasi awal yang dilakukan oleh peneliti, kabupaten Bengkulu Tengah merupakan daerah yang masih banyak dijumpai tumbuhan bambu. Salah satunya yaitu persebaran tumbuhan bambu di Desa Harapan Makmur Kecamatan Pondok Kubang Kabupaten Bengkulu Tengah. Lingkungan yang ada di sekitar SMPN 1 Pondok Kubang kebanyakan yaitu tumbuhan bambu. Tumbuhan bambu merupakan salah satu sumber belajar yang dapat dioptimalkan untuk pencapaian proses dan hasil pendidikan yang berkualitas bagi siswa.

Peran guru dalam proses pembelajaran sangatlah penting, salah satunya yaitu dalam menyampaikan materi pelajaran melalui bahan ajar. Adanya bahan ajar diharapkan materi pelajaran akan dapat dengan mudah dimengerti dan juga dapat melatih keterampilan proses sains siswa. Bahan ajar yang sering dipakai oleh guru salah satunya yaitu lembar kerja siswa (LKS). LKS yang dibuat hendaknya sesuai dengan kebutuhan siswa, diantaranya yaitu mudah dipahami, menarik, dan dapat melatih keterampilan proses sains siswa.Untuk dapat mewujudkan kebutuhan siswa maka guru harus kreatif dan dapat mengembangkan bahan ajar pembelajaran. Namun, pembelajaran yang selama ini diterapkan disekolah terhadap pengembangan keterampilan proses sains siswa belum dioptimalkan. Berdasarkan hasil observasi dan wawancara di SMPN 1 Pondok Kubang diketahui bahwa guru hanya menggunakan LKS pada materi tertentu dan sebagai penggantinya menggunakan LKS yang ada di buku. Sedangkan pembelajaran IPA sulit disampaikan hanya dengan menggunakan buku tanpa bantuan bahan ajar lain seperti LKS. Selain itu, guru juga masih mengandalkan LKS yang berasal dari penerbit, diketahui bahwa LKS tersebut belum memenuhi kebutuhan siswa. LKS ini hanya berisi ringkasan materi, pertanyaanpertanyaan, petunjuk kerja praktikum dan belum menggali keterampilan proses sains siswa secara keseluruhan. Isi LKS yang digunakan oleh siswa kelas VII di SMPN 1 Pondok Kubang kurang dapat membimbing siswa dalam meningkatkan keterampilan proses sains.

Pembelajaran dengan menggunakan LKS dapat memberikan pengalaman langsung kepada siswa karena siswa dapat mecari informasi dan mendapatkan konsep materi dengan sendirinya dengan mengikuti prosedur yang ada di dalam LKS. Mengingat pentingnya LKS yang baik dan dapat menunjang keterampilan proses sains siswa dalam proses pembelajaran, maka penelitian untuk mengembangkan LKS sangat diperlukan. Untuk itu peneliti ingin melakukan penelitian tentang identifikasi jenis tumbuhan bambu di desa Harapan Makmur.

Hasil dari penelitian tersebut akan dijadikan sebagai bahan pengembangan LKS SMP Kelas VII materi klasifikasi makhluk hidup sesuai dengan KD 6.2 
Mengklasifikasikan makhluk hidup berdasarkan ciri-ciri yang dimiliki. Berdasarkan kompetensi dasar tersebut di harapkan siswa mampu mengklasifikasikan jenis tumbuhan bambu berdasarkan identifikasi ciri-ciri yang dimiliki.

Dengan adanya penelitian mengenai keanekaragaman bambu di Desa Harapan Makmur yang dikembangkan dalam bentuk LKS ini, diharapkan siswa lebih memahami materi klasifikasi tumbuhan dan terlatih keterampilan prosesnya serta siswa dapat mengenal kondisi lingkungan yang ada disekitar melalui pengembangan LKS pada pembelajaran di sekolah.

Berdasarkan permasalahan tersebut dapat dirumuskan masalah dalam penelitian ini : 1)Bagaimana deskripsi hasil studi identifikasi jenis bambu di Desa Harapan Makmur Kabupaten Bengkulu Tengah? 2) Bagaimana deskripsi keterampilan proses siswa berdasarkan pengembangan LKS konsep klasifikasi tumbuhan hasil studi identifikasi jenis-jenis bambu Desa Harapan Makmur dalam pembelajaran IPA siswa kelas VII SMPN 1 Pondok Kubang Kabupaten Bengkulu Tengah?

Adapun tujuan dari penelitian ini adalah Untuk mendeskripsikan jenis bambu di Desa Harapan Makmur Kabupaten Bengkulu Tengah dan untuk mendeskripsikan keterampilan proses siswa berdasarkan pengembangan LKS konsep klasifikasi tumbuhan hasil studi identifikasi jenis bambu Desa Harapan Makmur pada pembelajaran IPA siswa kelas VII SMPN 1 Pondok Kubang Bengkulu Tengah.

\section{METODE}

Jenis penelitian ini adalah penelitian dan pengembangan dengan metode $(R \& D)$. Subyek penelitian ini adalah seluruh siswa kelas VII SMPN 01 Pondok Kubang Kabupaten Bengkulu Tengah tahun ajaran
2016/2017 dan tanaman bambu di Desa Harapan Makmur Kecamatan Pondok Kubang Kabupaten Bengkulu Tengah.

Teknik pengumpulan data yang digunakan dalam penelitian ini adalah : observasi, angket, wawancara. Untuk teknik analisis data yang di gunakan adalah : 1) Teknik analisis studi identifikasi jenis bambu, data yang diperoleh di analisis secara deskriptif yang mengacu pada buku acuan identifikasi bambu. Selanjutnya dibuat tabulasi ciri untuk melihat beda antar jenis bambu untuk pembuatan kunci determinasinya. 2)Teknik analisis hasil validasi LKS, data hasil validasi berupa data kuantitatif yang akan diubah menjadi data kualitatif. Skor yang didapat dari masingmasing angket dihitung menggunakan rumus dan disesuaikan dengan kategori penilaian ideal sebagai berikut

$$
P=\frac{\sum x}{\sum x i} \times 100 \%
$$

Keterangan:

$\mathrm{P} \quad=$ Persentase Kevalidan

$\Sigma \mathrm{Xi} \quad=$ jumlah nilai ideal per item

$\Sigma \mathrm{X}=$ jumlah jawaban responden per ite $100 \%=$ konstanta

3) Teknik analisis data angket respon guru dan siswa, Data angket tanggapan guru dan siswa terhadap LKS dianalisis dengan cara deskriptif persentase.

$$
\mathrm{P}=\frac{\mathrm{F}}{\mathrm{N}} x \mathrm{l} 00 \%
$$

Keterangan:

$\mathrm{P}=$ persentasepenilaian

$\mathrm{F}=$ skoryangdiperoleh

$\mathrm{Ya}=$ =skor 1

Tidak=skor 0

$\mathrm{N}=$ skor maksimal 
4) Teknik analisis data keterampilan proses dasar IPA

Data keterampilan yang diperoleh setiap kelompok dihitung menggunakan rumus konversi menurut Kemdikbud (2014):

$$
\text { nilai }=\frac{\text { Skor yang diperoleh }}{\text { skor maksimal }} \times 4
$$

Untuk melihat nilai keterampilan representatif setiap kelompok siswa dihitung dengan rumus rerata menurut Sudijono (2012) yaitu :

$$
\mathrm{X}=\frac{\sum X}{N}
$$

Keterangan:

$\Sigma X=$ Jumlah nilai yang diperoleh

$\mathrm{X}=$ Nilai rata-rata

$\mathrm{N}=$ Jumlah kelompok

\section{HASIL DAN PEMBAHASAN}

Berdasarkan penelitian yang telah dilakukan, jenis bambu di Desa Harapan Makmur Kecamatan Pondok Kubang Kabupaten Bengkulu Tengah, ditemukan bambu sebanyak 4 marga yaitu Bambusa, Dendrocalamus, dan Schizostachyum, Gigantochloa yang terdiri dari 5 jenis bambu. Dimana hasil penelitian tersebut dapat dilihat pada Tabel 4.1.

Tabel 4.1 Jenis-jenis bambu di Desa Harapan Makmur Kecamatan Pondok Kubang Kabupaten

\begin{tabular}{|c|c|c|c|c|}
\hline $\begin{array}{l}\mathbf{N} \\
\mathbf{O}\end{array}$ & $\begin{array}{l}\text { Nama } \\
\text { Lokal }\end{array}$ & $\begin{array}{l}\text { Nama } \\
\text { Genus }\end{array}$ & $\begin{array}{l}\text { Nama } \\
\text { Latin }\end{array}$ & $\begin{array}{l}\text { Jumlah } \\
\text { rumpun }\end{array}$ \\
\hline 1 & $\begin{array}{l}\text { Bambu } \\
\text { Kuning }\end{array}$ & Bambusa & $\begin{array}{l}\text { Bambusa } \\
\text { vulgaris } \\
\text { var.striata }\end{array}$ & 5 \\
\hline 2 & $\begin{array}{l}\text { Bambu.au } \\
\text { r cina }\end{array}$ & & $\begin{array}{l}\text { Bambusa } \\
\text { multiplex }\end{array}$ & 4 \\
\hline 3 & $\begin{array}{l}\text { Bambu } \\
\text { Betung }\end{array}$ & $\begin{array}{l}\text { Dendrocal } \\
\text { amus }\end{array}$ & $\begin{array}{l}\text { Dendrocalamu } \\
\text { s asper }\end{array}$ & 3 \\
\hline 4 & $\begin{array}{l}\text { Bambum } \\
\text { umbu }\end{array}$ & $\begin{array}{l}\text { Schizostac } \\
\text { hyum }\end{array}$ & $\begin{array}{l}\text { Schizostachyu } \\
\text { m lima }\end{array}$ & 7 \\
\hline 5 & $\begin{array}{l}\text { Bambu } \\
\text { Tali }\end{array}$ & $\begin{array}{l}\text { Gigantoch } \\
\text { loa }\end{array}$ & $\begin{array}{l}\text { Gigantochloa } \\
\text { apus }\end{array}$ & 10 \\
\hline
\end{tabular}
Bengkulu Tengah
Dari Tabel 4.1 diatas diketahui bahwa marga Gigantochloa di Desa Harapan Makmur merupakan marga yang paling banyak ditemukan pada lokasi penelitian, dikarenakan marga Gigantochloa merupakan marga/genus terbesar di Indonesia sehingga penyebarannya hampir menguasai seluruh wilayah di tiap-tiap daerah.

Sedangkan untuk marga yang paling sedikit ditemukan yaitu marga Dendrocalamus hanya 3 rumpun bambu. Untuk marga Dendrocalamus, populasi nya semakin sedikit dikarenakan rebung bambu ini selalu di ambil oleh masyarakat sekitar untuk sayuran dan juga marga dendrocalamus ini di gunakan sebagai bahan bangunan. Hal ini sejalan dengan pendapat Widjaja (2001b) yang melakukan penelitian jenis-jenis bambu di Kepulauan Sunda kecil yaitu marga Dendrocalamus digunakan sebagai bahan baku pembuatan rumah, kursi, dan dapat dijadikan sebagai bahan pangan yakni berupa rebung dari tumbuhan bambu marga ini.

Bambu yang terdapat di Desa Harapan Makmur dapat di temukan di kebun warga dan di pekarangan rumah warga. Jenis-jenis bambu yang ditemukan di Desa Harapan Makmur tersebut kemudian diidentifikasi berdasarkan persamaan dan perbedaan ciri morfologi rebung, batang, daun, pelepah dan percabangan dengan hasil identifikasi yang dibuat kunci determinasinya sebagai berikut :

Kunci Determinasi Tingkat Genus (marga)

1a. Memiliki diameter batang lebih dari $6 \mathrm{~cm}$ dan tebal lebih dari 1,5 cm, memiliki akar udara..................Dendrocalamus

b. Memiliki diameter batang kurang dari $5 \mathrm{~cm}$ dan tebal kurang dari $1 \mathrm{~cm}$, 


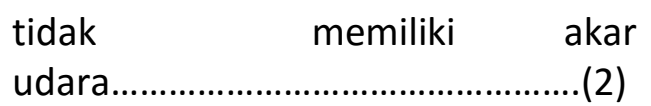

2. a. Memiliki cabang yang ukurannya sama

besar.

Schizostachyum

b. Memiliki cabang yang ukurannya satu cabang lebih besar

3. a. Posisi daun pelepah tegak.................................Bambusa

b.Posisi daun pelepah terlekuk terbalik.......................Gigantochloa

Kunci Determinasi Tingkat Spesies (Jenis)

1. a.Ruas batang memiliki akar udara .Dendrocalamus asper

b.Ruas batang tidak memiliki akar udara

2. a.Memiliki cabang yang ukurannya sama besar... Schyzostachyum lima

b.Memiliki cabang yang ukurannya satu cabang lebih besar.

3. a.Posisi daun pelepah tegak ..Bambusa vulgaris var. vulgaris

b.Posisi daun pelepah terkeluk terbalik................Gigantochloa robusta

Data dari lokasi penelitian kemudian dijadikan bahan sebagai penyusun lembar kerja siswa. LKS yang akan dikembangkan

\begin{tabular}{|c|c|c|c|c|c|c|c|c|}
\hline \multirow[t]{2}{*}{ No } & \multirow{2}{*}{$\begin{array}{c}\text { Kelompok } \\
\text { pengamatan }\end{array}$} & \multicolumn{6}{|c|}{ Indikator keterampilan } & \multirow[t]{2}{*}{ Nilai } \\
\hline & & $\begin{array}{c}\text { Menga } \\
\text {-mati }\end{array}$ & $\begin{array}{c}\text { Mengu } \\
\text {-kur }\end{array}$ & $\begin{array}{c}\text { Mempre } \\
\text {-diksi }\end{array}$ & $\begin{array}{l}\text { Menggo } \\
\text { lo-ngkan }\end{array}$ & $\begin{array}{l}\text { Menyim- } \\
\text { pulkan }\end{array}$ & $\begin{array}{l}\text { Mengkomu } \\
\text {-nikasikan }\end{array}$ & \\
\hline 1 & 1 & 3 & 3 & 3 & 3 & 3 & 3 & 4 \\
\hline 2 & 2 & 3 & 2 & 3 & 3 & 3 & 3 & 3,77 \\
\hline 3 & 3 & 3 & 3 & 3 & 3 & 3 & 3 & 4 \\
\hline 4 & 4 & 3 & 3 & 3 & 3 & 3 & 3 & 4 \\
\hline 5 & 5 & 3 & 2 & 3 & 3 & 3 & 3 & 3,77 \\
\hline \multirow[t]{4}{*}{6} & 6 & 3 & 2 & 2 & 3 & 3 & 3 & 3,5 \\
\hline & \multirow{2}{*}{\multicolumn{7}{|c|}{$\begin{array}{c}\text { Rerata nilai } \\
\text { Predikat }\end{array}$}} & 3,82 \\
\hline & & & & & & & & A \\
\hline & \multicolumn{7}{|c|}{$\begin{array}{c}\text { Predikat } \\
\text { Tingkat ketunt }\end{array}$} & Tunta \\
\hline
\end{tabular}

tersebut telah memiliki validitas yang logis dan dapat diimplementasikan pada pembelajaran Biologi SMP dengan materi klasifikasi tumbuhan di kelas VII SMPN 1 Pondok Kubang. Nilai respon validator dapat terlihat pada Tabel 4.2 dibawah ini :

Tabel 4.2. Respon Validator Terhadap LKS Klasifikasi Tumbuhan Bambu

\begin{tabular}{|c|c|c|c|}
\hline No. & Responden & $\begin{array}{c}\text { Rata-rata nilai } \\
\text { Pengembangan } \\
\text { LKS }\end{array}$ & Kriteria \\
\hline 1 & Validator 1 & $90 \%$ & $\begin{array}{l}\text { Valid/ } \\
\text { cukup } \\
\text { layak }\end{array}$ \\
\hline 2 & Validator 2 & $85 \%$ & $\begin{array}{l}\text { Valid/ } \\
\text { cukup } \\
\text { layak }\end{array}$ \\
\hline 3 & Validator 3 & $75 \%$ & $\begin{array}{l}\text { Valid/ } \\
\text { cukup } \\
\text { layak }\end{array}$ \\
\hline & Rerata & $83,33 \%$ & $\begin{array}{l}\text { Valid/ } \\
\text { cukup } \\
\text { layak }\end{array}$ \\
\hline
\end{tabular}

LKS yang telah memiliki validitas logis diimplementasikan dalam pembelajaran IPA materi klasifikasi tumbuhan . Rerata nilai keterampilan dari seluruh kelompok pengamatan adalah sebesar 3,82 dengan kategori sangat baik dan tuntas yang disajikan pada Tabel 4.5 


\begin{abstract}
Berdasarkan Tabel. 4.5 dapat diketahui bahwa penerapan LKS berdasarkan hasil studi identifikasi jenis bambu Desa Harapan Makmur pada materi klasifikasi tumbuhan berdasarkan pengamatan ciri morfologi dan kunci determinasinya dapat digunakan untuk melatih keterampilan proses dasar IPA siswa kelas VII. Meskipun hasil rerata nilai keterampilan proses setiap kelompok pengamatan tergolong sangat baik akan tetapi masih terdapat 1 indikator keterampilan proses yaitu keterampilan mengukur yang masih memperoleh skor 2 dari 3 kelompok pengamatan. Observasi dilakukan oleh 2 observer yaitu 1 orang guru biologi dan 1 orang calon guru biologi.

Dari hasil pengumpulan data dengan menggunakan lembar observasi yang dibantu oleh 2 observer diperoleh data ratarata tiap kelompok sebagai berikut:
\end{abstract}

Tabel 4.6 Nilai Rata-Rata Keterampilan Proses Sains

\begin{tabular}{|c|c|c|c|}
\hline No Kel & $\begin{array}{l}\text { Rata- } \\
\text { Rata }\end{array}$ & Predikat & $\begin{array}{c}\text { Ketunta } \\
\text { san }\end{array}$ \\
\hline 1 & 3.73 & $\begin{array}{l}\text { Sangat baik } \\
\text { (A-) }\end{array}$ & Tuntas \\
\hline 2 & 3.73 & $\begin{array}{l}\text { Sangat baik } \\
\text { (A-) }\end{array}$ & Tuntas \\
\hline 3 & 3.46 & $\begin{array}{l}\text { Baik } \\
(B+)\end{array}$ & Tuntas \\
\hline 4 & 3.37 & $\begin{array}{l}\text { Baik } \\
(B+)\end{array}$ & Tuntas \\
\hline 5 & 3.55 & $\begin{array}{l}\text { Baik } \\
(\mathrm{B}+)\end{array}$ & Tuntas \\
\hline 6 & 4,00 & $\begin{array}{l}\text { Sangat baik } \\
\text { (A) }\end{array}$ & Tuntas \\
\hline $\begin{array}{l}\text { Rerata } \\
\text { klasikal }\end{array}$ & 3.64 & Huruf $(A-)$ & $\begin{array}{c}100 \% \\
\text { Tuntas }\end{array}$ \\
\hline
\end{tabular}

Berdasarkan hasil identifikasi jenisjenis bambu yang disajikan pada Tabel 4.1 dapat diketahui bahwa jenis bambu yang ditemukan di Desa Harapan Makmur
Kabupaten Bengkulu Tengah memperoleh 4 marga bambu yang terdiri atas 5 jenis. Identifikasi yang dilakukan untuk membedakan karakteristik dari marga tumbuhan bambu yang ditemukan tersebut adalah dengan mengamati karakteristik pada jumlah rumpun, kerapatan, morfologi batang, percabangan, pelepah buluh, daun dan rebung. Hal ini sesuai dengan pendapat Solikin (2003) bahwa sebagian bambu yang diamati tidak berbunga sehingga untuk membedakan masing-masing marga didasarkan pada sifat morfologi vegetatif.

Berdasarkan identifikasi tumbuhan bambu yang dilakukan di Desa Harapan Makmur Kabupaten Rejang Lebong diketahui tiap marga tersebut memiliki ciri yang berbeda. Marga Bambusa mempunyai ciri yaitu adanya percabangan yang kuat dan tidak sama besar. Selain itu ciri khas dari genus Bambusa adalah permukaan batangnya yang mengkilap licin dengan ruas batang pendek $\pm 20-38 \mathrm{~cm}$, posisi daun pelepahnya yang tegak dan tidak memiliki akar udara pada buku-buku batangnya. Hal ini sesuai dengan ciri kelompok Bambusa menurut Arinasa (2004) bahwa ciri khas dari kelompok Bambusa ialah daun pelepah buluhnya tegak, batangnya licin, dan buku batangnya tidak memiliki akar udara.

Ciri khas dari genus Gigantochloa ialah permukaan batang berlapis lilin, posisi daun pelepah terkeluk balik, pelepah buluh yang mudah luruh dengan warna miang hitam dan coklat. Hal ini sejalan dengan penelitian yang dilakukan oleh Solikin (2003) di Kebun Raya Purwodadi yang menemukan ciri dari marga Gigantochloa yaitu mempunyai pelepah buluh mudah lepas dengan warna miang pada pelepah coklat. memiliki akar udara pada buku-buku bagian bawah batangnya. Hal ini juga sesuai dengan ciri khas genus Gigantochloa menurut Arinasa (2004) yaitu posisi daun pelepah 
buluh terkeluk terbalik dan menurut Irawan, dkk (2006) pada buku ruas batang ke 1-4 terdapat akar udaranya.

Ciri khas dari genus Dendrocalamus adalah ukuran diameter serta ketebalan dinding batangnya yang paling besar dari genus bambu yang lain.

Marga Schizostachyum yang ditemukan mempunyai ciri yaitu pelepah buluh tidak mudah luruh dan warna miang pada batang coklat, percabangan sama besar. Hal ini sejalan dengan penelitian yang dilakukan oleh Solikin (2003) di Kebun Raya Purwodadi yang menemukan ciri dari marga Schizostachyum yaitu pelepah buluh tidak mudah lepas dan warna miang pada batang pada batang coklat dan percabangan sama besar.

Berdasarkan Tabel 4.2 diatas diketahui rerata uji kelayakan LKS yaitu 83,33\% dengan kriteria sangat baik. Secara keseluruhan LKS yang dikembangkan memenuhi kriteria yang sangat baik. Adapun beberapa saran perbaikan yang disarankan oleh para validator seperti penambahan sekolah di cover depan LKS dan gambar pada LKS sebaiknya diperjelas.

Hasil validasi ini membuktkan bahwa LKS yang dibuat telah memenuhi kriteriariteria sebagai LKS yang baik yaitu telah sesui dengan kelompok sasaran, sesuai dengan tujuan yang akan dicapai, kualitas yang baik, sistematika penyusunan bahasan dan penyusunan yang telah benar. Setelah dilakukan validasi dan dinyatakan layak barulah LKS dapat diimplementasikan di sekolah. Menurut Prastowo (2011), suatu bahan ajar sebelum diterapkan ke dalam kelas, terlebih dahulu harus disusun secara sistematis dan teratur agar bahan ajar tersebut tidak membuat bingung siswa.

Hasil penelitian dalam uji coba menunjukkan bahwa Pengembangan LKS ini memiliki tingkat respon guru yang sangat tinggi yaitu 97,77\%. Pengembangan LKS ini cocok digunakan selama proses pembelajaran, dan pengembangan LKS berdasarkan hasil studi identifikasi tumbuhan bambu ini sangat mendukung proses pembelajaran. Selain itu juga pengembangan LKS berdasarkan hasil studi identifikasi tumbuhan bambu ini lebih memadai daripada LKS sebelumnya dan dapat membantu dalam menyampaikan materi klasifikasi tumbuhan.

Di samping itu berdasarkan respon siswa, memiliki tingkat respon yang sangat tinggi yaitu 90\%. kegiatan belajar dalam LKS menyenangkan, belajar biologi materi klasifikasi tumbuhan lebih mudah dipahami dengan menggunakan LKS. Hal ini ditunjukkan dengan antusiasme siswa dalam membaca dan melakukan kegiatan pembelajaran dalam LKS. Hal tersebut mengindikasikan bahwa siswa tertarik dengan isi LKS dan kegiatan yang ada di dalam Pengembangan LKS.

Aktivitas yang beragam tersebut menjadikan siswa tidak hanya paham mengenai materi Klasifikasi tumbuhan, tetapi juga dapat menumbuhkan rasa keingintahuan yang tinggi untuk menemukan konsep sendiri. Banyaknya siswa yang aktif diduga kuat karena LKS ini memuat kegiatan pembelajaran yang menarik dengan mengajak siswa untuk bersikap aktif yaitu praktikum, mengamati, bertanya, memperhatikan dan memberikan pendapatnya serta kreatif yang dirangsang dengan membuat produk. Aktivitas yang tinggi juga dikarenakan tanggapan siswa terhadap LKS sangat tinggi. Siswa menilai kegiatan dalam LKS mudah dipahami, menyenangkan, mampu membuka wawasan, dan meningkatkan minat belajar. Selain itu didukung oleh tanggapan guru bahwa pengembangan LKS dapat diterapkan dalam pembelajaran biologi. 
Berdasarkan Tabel 4.5 hasil rerata nilai keterampilan proses adalah sebesar 3,82 yang berkategori sangat baik dan tuntas sehingga menunjukkan penggunaan LKS yang dikembangkan berdasarkan hasil studi identifikasi jenis-jenis bambu Desa Harapan Makmur tersebut memang dapat digunakan untuk melatih keterampilan proses sains siswa kelas VII SMPN 1 Pondok Kubang Bengkulu Tengah pada materi klasifikasi tumbuhan berdasarkan ciri morfologi dan kunci determinasinya.

Berdasarkan dari Tabel 4.5 dapat terlihat bahwasanya masih terdapat nilai rata-rata keterampilan mengukur kelompok 2, 5 dan 6 mendapatkan angka 2,22 dengan huruf $\mathrm{C}$ dan bisa dikatakan rendah dibandingkan dengan nilai dari tiap indikator keterampilan sains lainnya, hal ini terjadi karena banyaknya siswa yang tidak mengetahui dan lupa cara penggunaan alat ukur yaitu alat ukur jangka sorong dengan pengukuran yang dilakukan siswa hasil pengukurannya belum akurat. Pada indikator keterampilan mengukur inilah siswa perlu bayak dilatih untuk menggunakan alat ukur dan perlunya perhatian yang lebih dari guru pada indikator keterampilan mengukur, agar kemampuan keterampilan mengukur siswa akan menjadi lebih baik.

Dapat juga dilihat bahwasanya berdasarkan Tabel 4.5 nilai rata-rata keterampilan mengamati semua kelompok mendapat nilai 4,00 dengan huruf $A$, hal ini dikarnakan siswa selalu melakukan pengamatan sesuai dengan aspek yang harus diamati dalam pengerjaan LKS dan siswa aktif dalam proses pembelajaran sehingga guru hanya berperan sebagai fasilitator. Keberhasilan tersebut tidak terlepas dari peran LKS yang dikembangkan berdasarkan hasil penelitian jenis bambu di Desa Harapan Makmur, hal ini sesuai dengan ungkapan Prastowo (2011), yang mengungkapkan bahwasanya salah satu fungsi LKS adalah sebagai bahan ajar yang meminimalkan peran pendidik, namun lebih mengaktifkan peserta didik dan keberadaan LKS yang kreatif dan inovatif menjadi harapan peserta didik karena dapat menciptakan proses pembelajaran menjadi lebih menyenangkan.

Keterampilan mengamati dilatihkan ketika siswa belajar mengamati ciri posisi daun pelepah dan percabangan dari masingmasing herbarium bambu tersebut. Kemudian siswa juga mencatat hasil pengamatannya pada tabel pengamatan LKS. Dalam proses pembelajaran menggunakan LKS tersebut, siswa juga dilatih keterampilan mengukur yaitu ketika siswa mengukur diameter dan ketebalan batang dari masing-masing herbarium batang bambu tersebut. Siswa dilatih untuk mampu menggunakan alat ukur yaitu penggaris dan dilatih membaca hasil pengukuran dengan teliti. Akan tetapi kemampuan mengukur dari semua kelompok pengamatan berkategori cukup tuntas. Hal ini disebabkan siswa belum terbiasa melatih keterampilan mengukurnya. Dalam proses pembelajaran masih ada siswa yang melakukan pengukuran dengan terburu-buru sehingga hasil pengukuran yang diperoleh menjadi kurang teliti.

Keterampilan memprediksi dilatihkan ketika siswa mencoba meramalkan ciri hasil pengamatan morfologi bambu dari tabel pengamatan yang sesuai dengan ciri-ciri yang tertera pada kunci determinasi bambu. Proses memprediksi siswa dituntun dari pertanyaan penuntun di LKS tersebut.

Keterampilan menggolongkan dilatihkan ketika siswa mengelompokkan herbarium 1, 2, 3 dan 4 tersebut sesuai nama 
genusnya masing-masing dengan benar. Dari ciri-ciri hasil pengamatan yang telah ia prediksi cocok dengan pola ciri yang disajikan dari kunci determinasi tadi, maka ia dapat mengikuti pola kunci determinasi tersebut untuk menemukan nama genus dari herbarium bambu tersebut. Kemampuan menyimpulkan dilatihkan ketika siswa mampu membuat simpulan hasil pengamatan sesuai dengan jawaban rumusan masalah yang disajikan dari LKS.

Kemudian kemampuan mengkomunikasikan dilatihkan ketika siswa dapat menyampaikan hasil pengamatan dan hasil simpulan kelompoknya di depan kelas. Berdasarkan data Tabel 4.6 diatas dapat diketahui rata-rata nilai dari masing-masing klompok yaitu kelompok 1 rata-rata 4,00, kelompok 2 rata-rata 3.77, kelompok 3 ratarata 4.00 , kelompok 4 rata-rata 3.88 , kelompok 5 rata-rata 3.77, kelompok 6 ratarata 3.55, sedangkan ketuntasan secara klasikal telah tercapai yaitu diperoleh nilai 3,82 dengan persentase ketuntasan mencapai $100 \%$ berdasarkan hasil ini dapat dikatakan keterampilan proses sains siswa telah tuntas.

Hasil rerata skor keterampilan mengamati, memprediksi, menggolongkan, menyimpulkan dan mengkomunikasikan dari semua kelompok pengamatan menunjukkan seluruh kelompok dapat melakukan keterampilan tersebut dengan sangat baik. Sehingga penggunaan LKS ini dapat digunakan dalam melatih keterampilan proses sains siswa tersebut terutama pada materi Klasifikasi Tumbuhan Berdasarkan Ciri Morfologi Dan Kunci Determinasinya ini. Hal ini sesuai dengan pendapat Widjajanti (2008) bahwa penyusunan LKS yang tepat memang dapat digunakan untuk mengembangkan keterampilan proses siswa.

\section{PENUTUP}

Simpulan

Jenis bambu yang terdapat di Desa Harapan Makmur Kecamatan Harapan Makmur Kabupaten Bengkulu Tengah terdiri atas 4 marga bambu dengan 5 jenis bambu yaitu Bambusa vulgaris var.vulgaris, Bambusa multiplex, Gigantochloa robusta, Schizostachyum lima, dan Dendrocalamus asper.

Keterampilan proses dalam proses pembelajaran IPA siswa kelas VII SMPN 1 Pondok Kubang Bengkulu Tengah pada materi klasifikasi tumbuhan berdasarkan ciri morfologi dan kunci determinasinya dapat terlatih terbukti dengan rerata nilai keterampilan 3,84 berkategori sangat baik dan tuntas

\section{Saran}

Berdasarkan hasil penelitian yang telah dilakukan, beberapa saran yang dapat dianjurkan yaitu, dapat dijadikan referensi bagi peneliti selanjutnya, dan produk hasil penelitian ini dapat digunakan dalam pembelajaran pada skala yang lebih luas.

\section{DAFTAR PUSTAKA}

Arikunto, Suharsimi.2013. Prosedur Penelitian Suatu Tindakan Praktik.Jakarta: Rineka cipta

Arinasa, Ida Bagus Ketut. 2004. Keanekaragaman dan Penggunaan Jenis-jenis Bambu di Desa Tigawasa, Bali. Bali : UPT Balai Konservasi Tumbuhan Kebun Raya "Eka Karya" Bali-LIPI.

Kemdikbud. 2014. Buku Guru IPA Edisi Revisi Kurikulum 2013 SMP kelas VII. Jakarta: Pusat Kurikulum dan Perbukuan, Balitbang, Kemdikbud. 
Mudjiono dan Dimyati. 2015. Belajar dan Pembelajaran. Jakarta: Rineka Cipta

Prastowo, Andi. 2011. Panduan Kreatif Membuat Bahan Ajar Inovatif. Jogjakarta: Diva Press.

Sudijono, A. 2012. Pengantar Statistik Pendidikan. Jakarta: Rajawali pers.

Solikin.2003. Jenis-Jenis tumbuhan suku Poaceae Di Kebun Raya Purwodadi. Bogor: LIPI

Widjaja ,E. A. 2001a. Identikit Jenis-Jenis Bambu di Jawa. Bogor: Puslitbang Biologi-LIPI

Widjajanti, Endang. 2008. Kualitas Lembar Kerja Siswa. Jurusan Pendidikan Kimia FMIPA. (Diakses tanggal 16 februari 2017). 